\title{
RESEARCHPAPER
}

\section{Efficacy of newer insecticides against the brinjal, Solanum melongena (L.) shoot and fruit borer, Leucinodes orbonalis (Guen.) in Karaikal district, U.T. of Puducherry}

\author{
C. KAMESHWARAN AND K. KUMAR
}

\begin{abstract}
Department of Entomology, Pandit Jawaharlal Nehru College of Agriculture and Research Institute, Karaikal, PUDUCHERRY (U.T.) INDIA

Email : kumarkaliaperumal@yahoo.co.in
\end{abstract}

Article Info :Received : 04.09.2014; Revised : 15.08.2015; Accepted : 01.09.2015

To evaluate the efficacy of newer insecticides against brinjal shoot and fruit borer, L. orbonalis, two supervised field experiments were conducted during Kharif 2010 (Field experiment I) and Rabi 2011 (Field experiment II) at Eastern farm of PAJANCOA and RI, Department of Horticulture, Karaikal with the variety PLR2, as an irrigated crop. Four rounds of foliar applications were given. Among the treatments the lowest mean per cent shoot damage was recorded in the treatment with chlorantraniliprole 20 SC @ 40 $\mathrm{g}$ a.i./ha followed by emamectin benzoate $25 \mathrm{WG} @ 11 \mathrm{~g}$ a.i./ha, carbaryl $50 \mathrm{WP}+$ wettable sulphur $50 \mathrm{WP} @ 500 \mathrm{~g}$ a.i./ha and were superior than the untreated check. From the field experiment I and II, the treatment with chlorantraniliprole 20 SC @ $40 \mathrm{~g}$ a.i./ha recorded lesser infestation of shoot and fruit borer $L$. orbonalis followed by emamectin benzoate 25 WG @ $11 \mathrm{~g}$ a.i./ha and were superior than the other treatments on number and weight basis. The highest yield was observed in the treatment with

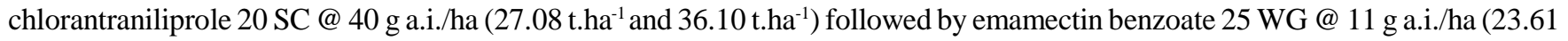
t.ha ${ }^{-1}$ and 32.66 t.ha $\left.^{-1}\right)$ compared to the untreated check $\left(14.20\right.$ tha $^{-1}$ and 18.46 t.ha $\left.^{-1}\right)$ and recorded maximum benefit cost ratio in the field experiment I and II, respectively.

Key words : Brinjal, Leucinodes orbonalis, Newer insecticides

How to cite this paper : Kameshwaran, C. and Kumar, K. (2015). Efficacy of newer insecticides against the brinjal, Solanum melongena (L.) shoot and fruit borer, Leucinodes orbonalis (Guen.) in Karaikal district, U.T. of Puducherry. Asian J. Bio. Sci., 10 (2) : $119-128$. 